\title{
Atypical employment relations by occupational sector in the European Union
}

Citation for published version (APA):

de Grip, A., Hoevenberg, J., \& Willems, E. (1995). Atypical employment relations by occupational sector in the European Union. Researchcentrum voor Onderwijs en Arbeidsmarkt, Faculteit der Economische Wetenschappen. ROA Research Memoranda No. 5E https://doi.org/10.26481/umaror.199505E

Document status and date:

Published: 01/01/1995

DOI:

10.26481/umaror.199505E

Document Version:

Publisher's PDF, also known as Version of record

\section{Please check the document version of this publication:}

- A submitted manuscript is the version of the article upon submission and before peer-review. There can be important differences between the submitted version and the official published version of record.

People interested in the research are advised to contact the author for the final version of the publication, or visit the DOI to the publisher's website.

- The final author version and the galley proof are versions of the publication after peer review.

- The final published version features the final layout of the paper including the volume, issue and page numbers.

Link to publication

\footnotetext{
General rights rights.

- You may freely distribute the URL identifying the publication in the public portal. please follow below link for the End User Agreement:

www.umlib.nl/taverne-license

Take down policy

If you believe that this document breaches copyright please contact us at:

repository@maastrichtuniversity.nl

providing details and we will investigate your claim.
}

Copyright and moral rights for the publications made accessible in the public portal are retained by the authors and/or other copyright owners and it is a condition of accessing publications that users recognise and abide by the legal requirements associated with these

- Users may download and print one copy of any publication from the public portal for the purpose of private study or research.

- You may not further distribute the material or use it for any profit-making activity or commercial gain

If the publication is distributed under the terms of Article $25 \mathrm{fa}$ of the Dutch Copyright Act, indicated by the "Taverne" license above, 


\section{Atypical employment relations by occupational sector in the European Union}

Andries de Grip, Jeroen Hoevenberg, Ed Willems

ROA-RM-1995/5E

A previous version of this paper has been presented at the Conference on the Challenges of Unemployment in a Regional Europe (CURE), Ameland, The Netherlands, 11-15 October 1994

Research Centre for Education and the Labour Market

Faculty of Economics and Business Administration University of Limburg

Maastricht, November 1995 


\section{CIP-GEGEVENS KONINKLIJKE BIBLIOTHEEK, DEN HAAG}

Grip, Andries de

Atypical employment relations by occupational sector in the European Union / Andries de Grip, Jeroen Hoevenberg, Ed Willems. - Maastricht : Research Centre for Education and the Labour Market, Faculty of Economics and Business Administration, University of Limburg. - (ROA-RM-1995/5E). A previous version of this paper has been presented at the Conference on the challenges of unemployment in a regional Europe (CURE), Ameland, the Netherlands, 11-15 October 1994. - Met lit. opg.

ISBN 90-5321-164-0

Trefw.: arbeidsmarkt ; Europese Unie / werkgelegenheid ; Europese Unie. 


\section{Contents}

page

Abstract

i

1 Introduction

2 Atypical employment by occupational sector

3 Convergence or divergence

4 Probabilities of having atypical employment

5 Conclusion

References 



\begin{abstract}
Unemployment is only one measure of labour market slack. Unstable labour market positions may also be indicated by involuntary part-time work and temporary contracts. In the period 1983-1991, there was no convergence between the employment shares of parttime work in EU countries. Some occupational sectors even show diverging trends. However, several occupational sectors show a slight convergence between the employment shares of temporary workers in the various EU countries. Analyses of the background characteristics of workers show that part-time work is positively related to female employment and the employment of young people and negatively related to the share of intermediate skilled workers in the workforce. The same characteristics, plus the share of older workers (with a negative sign), explain the share of workers with temporary contracts. However, if allowance is made for 'demand-side' occupational effects, gender is the only personal characteristic that increases the probability of part-time work, whereas personal characteristics no longer have significant effects on the probability of temporary work. Estimation results show that the occupational field in which a worker is employed significantly determines the probability of part-time employment. In particular, significantly more sales workers and service workers are employed in part-time jobs.
\end{abstract}





\section{Introduction}

As the OECD Employment Outlook 1993 notes, unemployment is only one measure of labour market slack. Unstable labour market positions may also be indicated by (involuntary) part-time work and temporary contracts. In the labour market literature, parttime and temporary forms of employment are both often labelled as 'contingent work', 'nonstandard' or 'atypical employment'. The phrase 'contingent employment arrangements' was used to indicate conditionality. It has been broadly defined as 'any arrangement which differs from full-time, permanent, wage and salary employment' (Polivka \& Nardone, 1989). More recently this kind of employment relationship is often described as 'atypical employment'. Delsen (1991) provides a definition of atypical employment which is broadly similar to the definition of contingent work: 'Atypical employment relations are those that deviate from full-time open-ended wage employment: part-time work, labour on-call contracts, min-max contracts, fixed-term contracts, seasonal work, agency work, homebased work, telework, apprenticeship contracts, freelancers, self-employment and informal work'.1

Treu (1992), however, prefers to speak of 'precarious' employment, since such employment relations have already proliferated to such an extent that it is no longer appropriate to use the term 'atypical'. According to Treu, the introduction of different types of employment contract has probably been the major development in European law and practice in the labour field during the past 15 years, and has played a leading role in increasing labour market flexibility. We will however use the term 'atypical' throughout this paper, as these employment relations are still non-standard.

The reasons for the increasing relevance of atypical employment relations can be found on both the demand and the supply sides of the labour market. On the demand side, the main reason for seeking more flexible employment relations is the need to be better able to adapt quickly to market fluctuations. On the employees' side, some forms of atypical work might meet the needs of those whose life circumstances prevent them from working fulltime (see also Treu, 1992). Delsen (1991) distinguishes between the two major forms of atypical employment: part-time and temporary work. Whereas employers' flexibility needs would be the main cause of the growth in temporary work, the main reason for introducing part-time work would be the demand for part-time jobs from female employees.

Tilly (1991) breaks down part-time work into three categories: (1) short-time, (2) secondary

1. See also Córdova (1986); Kravaritou-Manitakis (1988); Rodgers and Rodgers (1989), Treu (1992), Delsen (1995) and Meulders et al. (1995). 
part-time jobs and (3) retention part-time jobs. Short-time part-time employment occurs when, instead of dismissing workers during an economic recession, a firm temporarily reduces workers' hours. This kind of 'involuntary' part-time work is particularly common in cyclically sensitive sectors within the manufacturing sector. Secondary part-time jobs are the 'bad' part-time jobs on the secondary labour market (as defined in dual labour market theory: see e.g. Doeringer \& Piore, 1971). These 'involuntary' part-time jobs are bad jobs in terms of low pay and fringe benefits, lack of social protection, lack of career opportunities and high turnover, and they generally relate to low-skilled work. ${ }^{2}$ An increase in these secondary part-time jobs will be induced by the demand side of the labour market. It may be caused by a growing demand for these workers as a result of the relatively rapid growth of economic sectors that use the most part-timers, or by an increase in part-time work within industries due to changes in firms' employment strategies.

Retention part-time jobs, in contrast, are the 'good' part-time jobs created to retrain or attract (highly-) skilled employees who prefer to work part-time. These 'voluntary' part-time jobs are introduced to encourage labour market participation by women (or men) with dependent children, disabled workers or older workers (Delsen, 1993). An increase in these retention part-time jobs might be due to the increased flows of these groups of workers entering the labour market.

Temporary jobs are generally considered to be bad jobs created to increase employment flexibility for employers. ${ }^{3}$ This holds for both the 'traditional reasons' for temporary contracts (seasonal work, replacement of personnel during holidays or sickness, etc.) and the 'new reasons': firms' need to avoid permanent recruitment because of uncertainty (Marshall, 1989). Particularly in countries where a great deal of administrative and legal protection is given to permanent jobs, temporary jobs reflect employers' desire to facilitate lay-offs (Rodgers, 1989). For workers in temporary employment, the insecurity and inability to plan for the future are probably the primary threat. Another threat is that the degree of social protection accorded to temporary work is usually much less than for permanent work (Burchel, 1989; Marshall, 1989; Delsen, 1991). Temporary jobs can therefore be situated on the secondary segment of the labour market. However, temporary contracts are not restricted to low-skilled work. Sometimes temporary contracts are also a means of screening workers before final commitment (Marshall, 1989). In some countries fixed-term contracts have become a quite normal mode of entry into the labour market for young

2. See e.g. Cousins (1992) and Delsen (1991) for an analysis of the extent of social security provisions for atypical workers.

3. Rodgers (1989), however, argues that in any particular 'atypical ' employment category there is some bi-modality with regard to the quality of the jobs. 
workers, in particular in labour market segments characterized by high (youth) unemployment (Treu, 1992). Temporary employment is then often associated with periods of unemployment (Marshall, 1989).

This paper will focus on the two major forms of atypical employment relations mentioned above: part-time work and temporary employment contracts. We will describe these forms of atypical employment relations in the various Member States of the European Union, and the changes which are taking place. In contrast to most other studies, which have analyzed the importance of part-time and temporary work at a national level or at the level of the various economic sectors, the analysis in this paper focuses on the occupational sectors. The paper first deals with the following three questions:

- Which occupational sectors and countries show high rates of atypical employment relations?

- Where are increases in atypical work located?

- Is there a convergence or a divergence, between the European Union Member States, in the prevalence of atypical employment relations in the various occupational fields?

Then we will focus on the major research question of the paper:

- To what extent do supply-side personal background characteristics of the workforce and demand-side occupational characteristics determine atypical employment relations?

The empirical analyses will be based on EUROSTAT Labour Force Survey data on employment by occupational sector ${ }^{4}$ for eleven Member States of the European Union (EU). We will focus on a cross-country analysis for the year 1991, and on developments in the various occupational fields in the period $1987-1991 .{ }^{5}$ Unfortunately no comparable data is available for Italy. Because of the very small numbers for Luxembourg, small absolute changes can lead to enormous relative changes, so we have decided to present the data for this country, but not to interpret it.

The paper is organised as follows. Section 2 will give an overview of the relative importance of part-time work and temporary employment in the various occupational sectors in the Member States of the European Union. Section 3 asks whether there is convergence or divergence in the relative importance of these two forms of atypical employment relations between the European Union Member States, in each of the various occupational sectors. In Section 4 we present the results of a binomial-logit analysis of the

4. The occupational sectors refer to the 1-digit level of the International Standard Classification of Occupations (ISCO) 1968.

5. The convergency analyses refer to the period 1983-1991. Unfortunately the available data for 1992 and 1993 cannot be integrated in the analyses as it is based on the ISCO 1988 classification. 
relevance of various personal background and occupational characteristics for the probability that workers will be employed in part-time or in temporary work. Finally, Section 5 summarizes the main results of this paper.

\section{Atypical employment by occupational sector}

\section{Part-time work}

Table 1

Percentage of workers with part-time jobs, by occupational sector, in the European Union, 1991

\begin{tabular}{|c|c|c|c|c|c|c|c|c|}
\hline & $\begin{array}{c}\text { prof. } \\
\text { workers } \\
\%\end{array}$ & $\begin{array}{c}\text { man. } \\
\text { workers } \\
\%\end{array}$ & $\begin{array}{c}\text { clerical } \\
\text { workers } \\
\%\end{array}$ & $\begin{array}{c}\text { sales } \\
\text { workers } \\
\%\end{array}$ & $\begin{array}{c}\text { service } \\
\text { workers } \\
\%\end{array}$ & $\begin{array}{c}\text { agri. } \\
\text { workers } \\
\%\end{array}$ & $\begin{array}{c}\text { production } \\
\text { workers } \\
\%\end{array}$ & $\begin{array}{c}\text { total } \\
\%\end{array}$ \\
\hline Belgium & 14.9 & 4.0 & 13.7 & 13.1 & 30.4 & 6.4 & 3.1 & 11.7 \\
\hline \multicolumn{9}{|l|}{ Federal Republic } \\
\hline of Germany & 16.0 & 4.4 & 22.1 & 23.7 & 32.5 & 16.5 & 4.3 & 15.1 \\
\hline Denmark & 26.9 & 4.8 & 24.6 & 26.7 & 47.2 & 11.0 & 13.9 & 22.6 \\
\hline Greece & 3.9 & 0.7 & 2.6 & 3.1 & 5.1 & 5.0 & 2.2 & 3.4 \\
\hline Spain & 5.7 & 0.8 & 2.7 & 4.3 & 14.8 & 4.6 & 1.3 & 4.5 \\
\hline France & 10.5 & 1.3 & 15.1 & 12.7 & 27.4 & 13.1 & 3.3 & 11.9 \\
\hline Ireland & 8.2 & - & 8.6 & 11.7 & 20.6 & 5.9 & 3.9 & 8.3 \\
\hline Luxembourg & 6.6 & - & 7.0 & 5.9 & 22.0 & 7.6 & 3.0 & 7.5 \\
\hline Netherlands & 36.5 & 11.9 & 33.0 & 41.6 & 63.0 & 29.0 & 12.5 & 32.4 \\
\hline Portugal & 4.3 & 1.1 & 1.7 & 4.6 & 13.5 & 13.1 & 2.7 & 5.8 \\
\hline United Kingdom & 18.8 & 7.2 & 27.3 & 34.2 & 50.4 & 9.8 & 6.9 & 22.3 \\
\hline European Union & 16.0 & 5.6 & 19.3 & 20.9 & 33.8 & 11.0 & 4.6 & 15.0 \\
\hline
\end{tabular}

Source: EUROSTAT/ROA

From table 1 we can see that in 1991 an average of $15 \%$ of the total working population in the Member States of the European Union worked on a part-time basis. ${ }^{6}$ This is a few percentage points lower than Tilly (1991) finds for the USA in 1989. The differences between the various Member States are however very large. The Netherlands has by far

6. The full-time/part-time distinction of EUROSTAT is generally made on the basis of a spontaneous answer given by the person interviewed. However, there are two exceptions. In Greece, a person works part-time if he or she works fewer hours than those provided for in collective agreements applicable for that type of job. In the Netherlands, self-employed or family workers work part-time if they usually work less than 35 hours. Employees work parttime their contractual hours are less than 31 , or if they are between 31 and 34 but considered to be less than those normally worked for a job of that type. Marshall (1989) indicates that most part-time employment is actually concentrated around 20 hours per week. 
the largest proportion of its workforce in part-time employment (32.4\%). As Marshall (1989) says, part-time employment in this country, in particular for women, can hardly be called non-standard. On the other hand, Greece, Spain and Portugal have relatively small proportions of part-time workers. The table shows that, in all countries, the differences between the various occupational sectors are very large. Some $33.8 \%$ of all service workers have part-time jobs, whereas only $4.6 \%$ of all production workers and $5.6 \%$ of all managerial employees work part time. On average, about $20 \%$ of the people employed in the sales and clerical work sectors have part-time jobs. In the Netherlands and the United Kingdom more than half of the service workers have part-time jobs, as do almost half of the service workers in Denmark. The same three countries show the highest proportions of sales workers and clerical workers with part-time jobs.

As mentioned in Section 1, part-time work can be divided into short-time working, demandside driven 'involuntary' secondary part-time jobs, and supply-side driven 'voluntary' retention part-time jobs. Since the secondary part-time jobs are mainly low-skilled jobs, whereas the retention part-time jobs are mostly highly-skilled jobs, we assume that the part-time work in each occupational sector can be classified in these two categories. ${ }^{7}$ Service workers, agricultural workers, production workers and sales workers can be characterized as the low-skilled occupational sectors. ${ }^{8}$ Part-time jobs in these occupational sectors are therefore classified as secondary part-time work. The professional workers and the managerial workers are the highly-skilled occupational sectors, while the clerical workers are typically skilled at an intermediate level. We will consider the part-time jobs in these three occupational sectors as the retention part-time jobs.

Overall, $44 \%$ of all part-time jobs in the European Union could be classified as retention part-time work, of which about $45 \%$ refer to highly-skilled workers and $55 \%$ to intermediate skilled retention part-time jobs. This means that the majority of the part-time jobs relate to secondary part-time work. However table 2 shows that, in particular in the intermediate skilled occupational sectors, retention part-time work is even more prevalent than secondary part-time work in the low-skilled occupations. The table also ranks the various Member States according to the relative importance of retention part-time work and secondary part-time jobs. It appears that the overall rankings of countries with regard to

7. Since the labour force survey data does not enable us to distinguish between voluntary and involuntary part-time jobs, the distinction between retention and secondary part-time jobs could only be based on the average educational level of the occupational sectors.

8. In all EU countries, except for the Federal Republic of Germany, more than $50 \%$ of total employment in the first three occupational sectors relates to unskilled or low-skilled workers. On average, about $49 \%$ of sales workers are unskilled or low-skilled (Hoevenberg and De Grip, 1994). We may assume that part-time work in this occupational sector refers to secondary jobs. 
retention and secondary part-time jobs are quite similar. The only deviations are due to the high prevalence of retention part-time jobs at intermediate level in Germany, the United Kingdom and France, the low prevalence of retention part-time jobs among highly-skilled professions in the United Kingdom, and the high prevalence of secondary part-time jobs in Portugal.

Table 2

Percentages of jobs in the European Union classified as retention part-time and secondary part-time jobs, 1991.

\begin{tabular}{|c|c|c|c|c|c|c|}
\hline country & $\begin{array}{c}\text { retention } \\
\text { part-time jobs } \\
\text { (highly-skilled) } \\
1991 \\
\%\end{array}$ & position & $\begin{array}{c}\text { retention } \\
\text { part-time jobs } \\
\text { (intermediate skilled) } \\
1991 \\
\%\end{array}$ & position & $\begin{array}{c}\text { secondary } \\
\text { part-time jobs } \\
\text { (low-skilled) } \\
1991 \\
\%\end{array}$ & position \\
\hline Netherlands & 32.5 & (1) & 33.0 & (1) & 32.1 & (1) \\
\hline Denmark & 23.5 & (2) & 24.6 & (3) & 21.4 & (3) \\
\hline $\begin{array}{l}\text { United Kingdom } \\
\text { Federal Republic }\end{array}$ & 16.1 & (3) & 27.3 & (2) & 23.2 & (2) \\
\hline of Germany & 14.1 & (4) & 22.1 & (4) & 13.0 & (4) \\
\hline Belgium & 13.2 & (5) & 13.7 & (6) & 10.3 & (6) \\
\hline France & 10.3 & (6) & 15.1 & (5) & 11.3 & (5) \\
\hline Luxembourg & 8.3 & (7) & 7.0 & (8) & 8.6 & (7) \\
\hline Ireland & 7.0 & (8) & 8.6 & (7) & 8.5 & (8) \\
\hline Spain & 5.0 & (9) & 2.7 & (9) & 4.7 & (10) \\
\hline Portugal & 3.8 & (10) & 1.7 & (11) & 6.9 & (9) \\
\hline Greece & 3.5 & (11) & 2.6 & (10) & 3.5 & (11) \\
\hline European Union & 14.1 & & 19.3 & & 13.9 & \\
\hline
\end{tabular}

Source: EUROSTAT/ROA

Table 3 indicates that, for female workers, the prevalences of both retention and secondary part-time jobs are much higher than the average figures shown in table 2 . Although the rankings of countries with regard to retention and secondary part-time jobs are once again quite similar, the figures show that part-time jobs for female workers are more common in the secondary market than the retention part-time jobs at the intermediate or highly-skilled level. Moreover, in most countries retention part-time jobs are less prevalent within the intermediate skilled occupations than within the highly-skilled occupations. The reverse occurs only in the United Kingdom, Germany and France. 
Table 3

Percentages of jobs, for female workers in the European Union, which are classified as retention or secondary part-time jobs, 1991.

\begin{tabular}{|c|c|c|c|c|c|c|}
\hline country & $\begin{array}{c}\text { retention } \\
\text { part-time jobs } \\
\text { (highly-skilled) } \\
1991 \\
\%\end{array}$ & position & $\begin{array}{c}\text { retention } \\
\text { part-time jobs } \\
\text { (intermediate skilled) } \\
1991 \\
\%\end{array}$ & position & $\begin{array}{c}\text { secondary } \\
\text { part-time jobs } \\
\text { (low-skilled) } \\
1991 \\
\%\end{array}$ & position \\
\hline Netherlands & 57.6 & (1) & 48.7 & (1) & 68.5 & (1) \\
\hline Denmark & 35.7 & (2) & 30.9 & (4) & 43.3 & (3) \\
\hline United Kingdom & 31.8 & (3) & 35.1 & (2) & 56.0 & (2) \\
\hline Germany & 30.8 & (4) & 33.5 & (3) & 36.0 & (4) \\
\hline Belgium & 26.6 & (5) & 24.0 & (5) & 30.5 & (5) \\
\hline France & 18.7 & (6) & 20.8 & (6) & 27.0 & (6) \\
\hline Luxembourg & 17.8 & (7) & 11.9 & (7) & 22.9 & (8) \\
\hline Ireland & 13.9 & (8) & 11.4 & (8) & 24.0 & (7) \\
\hline Spain & 7.7 & (9) & 4.4 & (9) & 14.1 & (9) \\
\hline Greece & 6.0 & (10) & 4.2 & (10) & 7.2 & (11) \\
\hline Portugal & 4.0 & (11) & 2.2 & (11) & 12.9 & (10) \\
\hline European Union & 27.6 & & 28.0 & & 34.9 & \\
\hline
\end{tabular}

Source: EUROSTAT/ROA

As table 4 shows, the average employment share of part-time workers increased by 1 percentage point in the period 1987-1991. This means that, in contrast to the developments in the USA (see Larson and Ong, 1994), in the EU the prevalence of parttime work is still increasing. However, there are opposing trends in the various EU countries. The proportion of workers with part-time jobs decreased by 1.5 percentage points in Denmark and Greece and by 1 percentage point in Spain, whereas in the other EU Member States the proportion of part-time workers increased. The Netherlands, the Federal Republic of Germany and Belgium had the greatest increases in the prevalence of part-time employment, with rises of $3.1,2.8$ and 2 percentage points, respectively.

The table shows that the largest increase in part-time work occurred in the occupational classes in which part-time work can be classified as retention part-time work: for clerical workers, managerial workers and professional workers. The highest increase in secondary part-time employment was for the sales workers. The much higher increase in retention part-time employment probably reflects the narrowing of the labour market at the end of the 1980s in most EU Member States, which made it more important for employers to retain or attract workers who prefer to work part-time themselves. This pattern is most marked in the United Kingdom, where the relatively high increases in retention part-time work clearly contrast with decreases in secondary part-time work in the low-skilled occupational sectors. The Netherlands and Germany exhibit large increases in part-time 
work in almost all occupational sectors, whereas in Greece the proportion of part-time employment decreased in all occupational sectors. Denmark shows particularly large decreases in secondary part-time employment among sales workers and service workers and retention part-time work among clerical workers.

Table 4

Percentage points change in the number of part-time workers by occupational sector in the European Union in the period 1987-1991

\begin{tabular}{|c|c|c|c|c|c|c|c|c|}
\hline & $\begin{array}{c}\text { prof. } \\
\text { workers } \\
\%\end{array}$ & $\begin{array}{c}\text { man. } \\
\text { workers } \\
\%\end{array}$ & $\begin{array}{c}\text { clerical } \\
\text { workers } \\
\%\end{array}$ & $\begin{array}{c}\text { sales } \\
\text { workers } \\
\%\end{array}$ & $\begin{array}{c}\text { service } \\
\text { workers } \\
\%\end{array}$ & $\begin{array}{c}\text { agri. } \\
\text { workers } \\
\%\end{array}$ & $\begin{array}{c}\text { production } \\
\text { workers } \\
\%\end{array}$ & $\begin{array}{c}\text { total } \\
\%\end{array}$ \\
\hline $\begin{array}{l}\text { Belgium } \\
\text { Federal Republic }\end{array}$ & 2.3 & 2.1 & 1.7 & 1.2 & 4.4 & 0.2 & 0.4 & 2.0 \\
\hline of Germany & 3.4 & 1.4 & 3.0 & 4.3 & 6.1 & 0.0 & 0.8 & 2.8 \\
\hline Denmark & -0.1 & 3.1 & -2.6 & -7.7 & -2.8 & 3.2 & 0.5 & -1.5 \\
\hline Greece & -1.6 & -0.2 & -2.6 & -1.0 & -0.8 & -2.6 & -0.5 & -1.5 \\
\hline Spain & -1.0 & 0.0 & -0.8 & -1.6 & -0.8 & -1.2 & -0.9 & -1.0 \\
\hline France & 0.2 & -2.5 & 1.7 & 0.3 & 0.3 & -0.7 & -0.3 & 0.4 \\
\hline Ireland & 1.6 & - & 2.0 & 2.5 & 2.5 & -0.3 & 0.6 & 1.3 \\
\hline Luxembourg & 1.9 & - & 3.0 & -1.3 & -1.7 & 2.1 & 1.0 & 1.0 \\
\hline Netherlands & 2.0 & -0.3 & 4.6 & 3.2 & 3.3 & 6.1 & 0.5 & 3.1 \\
\hline Portugal & 1.0 & 0.4 & 0.4 & -1.1 & -1.7 & 4.0 & 0.0 & 0.3 \\
\hline United Kingdom & 1.1 & 2.7 & 2.0 & 1.7 & -2.4 & -5.6 & -0.4 & 1.1 \\
\hline European Union & 1.0 & 1.5 & 1.6 & 1.0 & 0.4 & -0.3 & -0.1 & 1.0 \\
\hline - below threshol & & & & & & & & \\
\hline
\end{tabular}

Source: EUROSTAT/ROA

\section{Temporary work}

In the European Union, $9.3 \%$ of the total workforce are employed under temporary contracts. $^{9}$ This means that temporary jobs are a substantially less wide-spread phenomenon than part-time work, which accounts for $15 \%$ of total employment in the European Union. Table 5 shows that in general the differences between the Member States are not extremely large. Belgium has the smallest proportion of workers on temporary contracts, with $4 \%$, and Spain has the largest proportion, at $24.1 \%$. Portugal, which has the second highest proportion, has just $11.9 \%$. The table shows relatively low prevalences of temporary employment for Ireland, the Netherlands and the United Kingdom. In Spain the prevalence of temporary work is high for all occupational sectors,

9. A job is regarded as temporary if the termination of the job is determined by objective conditions such as reaching a certain date, completion of an assignment, or the return of an employee who has been temporarily replaced. In such cases the condition for termination is generally mentioned in the contract. 
except for the managerial workers. No countries show clear deviations from the general pattern.

Table 5

Percentage of workers with temporary contracts by occupational sector in the European Union, 1991

\begin{tabular}{|c|c|c|c|c|c|c|c|c|}
\hline & $\begin{array}{c}\text { prof. } \\
\text { workers } \\
\%\end{array}$ & $\begin{array}{c}\text { man. } \\
\text { workers } \\
\%\end{array}$ & $\begin{array}{c}\text { clerical } \\
\text { workers } \\
\%\end{array}$ & $\begin{array}{c}\text { sales } \\
\text { workers } \\
\%\end{array}$ & $\begin{array}{c}\text { service } \\
\text { workers } \\
\%\end{array}$ & $\begin{array}{c}\text { agri. } \\
\text { workers } \\
\%\end{array}$ & $\begin{array}{c}\text { prod. } \\
\text { workers } \\
\%\end{array}$ & $\begin{array}{c}\text { total } \\
\%\end{array}$ \\
\hline $\begin{array}{l}\text { Belgium } \\
\text { Federal Republic }\end{array}$ & 5.8 & - & 5.1 & 2.2 & 6.8 & - & 2.4 & 4.0 \\
\hline of Germany & 9.1 & 3.8 & 7.0 & 7.2 & 9.0 & 5.4 & 8.9 & 8.1 \\
\hline Denmark & 11.6 & - & 9.6 & 10.7 & 12.5 & 5.2 & 11.6 & 10.5 \\
\hline Greece & 7.4 & - & 6.2 & 4.3 & 11.4 & 1.7 & 13.8 & 7.9 \\
\hline Spain & 18.7 & 2.2 & 22.6 & 16.4 & 28.1 & 20.0 & 29.4 & 24.1 \\
\hline France & 9.3 & - & 8.4 & 5.0 & 12.7 & 3.4 & 8.9 & 8.7 \\
\hline Ireland & 6.7 & - & 7.3 & 3.9 & 10.2 & - & 4.9 & 5.3 \\
\hline Luxembourg & - & - & 1.7 & 2.2 & 4.1 & - & 2.5 & 2.0 \\
\hline Netherlands & 8.8 & - & 7.4 & 4.7 & 8.5 & 4.1 & 5.9 & 6.7 \\
\hline Portugal & 10.4 & - & 11.8 & 8.5 & 15.9 & 5.1 & 15.5 & 11.9 \\
\hline United Kingdom & 6.2 & 1.1 & 5.5 & 5.0 & 7.5 & 4.6 & 2.6 & 4.8 \\
\hline European Union & 9.1 & 1.7 & 8.4 & 7.1 & 12.3 & 7.2 & 10.6 & 9.3 \\
\hline below thresho & & & & & & & & \\
\hline
\end{tabular}

Source: EUROSTAT/ROA

As has been mentioned in Section 1, employers' flexibility needs are generally considered to be the main cause for the growth in temporary contracts. From a worker's point of view, temporary work relates to 'bad' jobs that offer no career opportunities. For this reason we might expect that the percentage of workers with temporary contracts would be highest in the occupational sectors in which many jobs are located in the secondary labour market. Indeed the majority of temporary work (63\%) refers to the low-skilled occupations. Table 5 shows that the low-skilled occupational sectors of 'service workers' and 'production workers' have the highest proportions of workers with temporary contracts. However, the professional workers and clerical workers' sectors also have a considerable prevalence of temporary employment. It should be noted here that apprenticeships are also generally covered by temporary contracts. ${ }^{10}$

As Treu (1992) stated, temporary contracts have become a quite normal mode of entry into the labour market, which also holds for highly-skilled professional workers. Among

10. This also explains the somewhat higher proportion of temporary employment among professional workers in Germany. 
managerial workers, temporary contracts are a very rare phenomenon, which is in accordance with True's statement, since managerial jobs are generally not labour market entry jobs.

Table 6 shows that the average proportion of workers on a temporary contract increased by 1.4 percentage points in the period 1987-1991. This means that the growth rate of temporary jobs has been substantially higher than that of part-time employment. Remarkably, in Spain the proportion employed on a temporary basis increased by 13.2 percentage points. This increase cannot be due to a change in measurement methods, because there is a steady upward trend in the proportion of workers with temporary contracts. Obviously there must have been a shift in employment policies in Spain. This appears even more peculiar when we see that France has the second biggest increase, but with only 2.7 percentage points. In five other countries the proportions decreased, with the largest decreases in Germany ( -1.9 percentage points) and the Netherlands ( -1.3 percentage points). On average, the growth in temporary work has been highest among service workers and production workers, while among agricultural workers and sales workers, in particular, the growth is more moderate.

Table 6

Percentage points change in the number of workers with temporary contracts by occupational sector in the European Union in the period 1987-1991

\begin{tabular}{|c|c|c|c|c|c|c|c|}
\hline & $\begin{array}{c}\text { prof. } \\
\text { workers } \\
\% \text {-points }\end{array}$ & $\begin{array}{c}\text { clerical } \\
\text { workers } \\
\% \text {-points }\end{array}$ & $\begin{array}{c}\text { sales } \\
\text { workers } \\
\% \text {-points }\end{array}$ & $\begin{array}{c}\text { service } \\
\text { workers } \\
\% \text {-points }\end{array}$ & $\begin{array}{c}\text { agri. } \\
\text { workers } \\
\% \text {-points }\end{array}$ & $\begin{array}{c}\text { prod. } \\
\text { workers } \\
\% \text {-points }\end{array}$ & $\begin{array}{c}\text { total } \\
\% \text {-points }\end{array}$ \\
\hline Belgium & -0.3 & -0.5 & 0.4 & -0.4 & - & -1.0 & -0.4 \\
\hline Federal Republic & & & & & & & \\
\hline $\begin{array}{l}\text { of Germany } \\
\text { Denmark }\end{array}$ & $\begin{array}{r}-1.1 \\
2.3\end{array}$ & $\begin{array}{l}-1.9 \\
-0.9\end{array}$ & $\begin{array}{l}-2.6 \\
-0.1\end{array}$ & $\begin{array}{r}-2.4 \\
3.2\end{array}$ & $\begin{array}{r}-0.8 \\
0.2\end{array}$ & $\begin{array}{l}-2.4 \\
-0.7\end{array}$ & $\begin{array}{r}-1.9 \\
0.3\end{array}$ \\
\hline $\begin{array}{l}\text { Denmark } \\
\text { Greece }\end{array}$ & -0.6 & 0.9 & 0.9 & $\begin{array}{l}-2.2 \\
-2.1\end{array}$ & $\begin{array}{l}0.2 \\
-0.9\end{array}$ & -1.4 & $\begin{array}{r}0.3 \\
-0.6\end{array}$ \\
\hline Spain & 10.0 & 13.8 & 10.8 & 14.9 & 7.5 & 16.6 & 13.2 \\
\hline France & 4.1 & 2.6 & 1.4 & 4.8 & 0.9 & 1.7 & 2.7 \\
\hline Ireland & -0.7 & 1.8 & 0.7 & -0.3 & - & -0.4 & 0.2 \\
\hline Luxembourg & - & 0.3 & -2.3 & -0.8 & - & 0.3 & -0.2 \\
\hline Netherlands & -1.6 & -0.5 & -3.3 & -0.6 & -4.0 & -1.1 & -1.3 \\
\hline Portugal & 2.4 & 3.3 & 0.9 & -0.3 & -1.6 & -1.3 & 0.0 \\
\hline United Kingdom & -0.9 & 0.4 & 0.1 & -0.5 & -4.7 & -1.8 & -0.7 \\
\hline European Union & 1.2 & 1.4 & 1.0 & 2.5 & 0.7 & 1.6 & 1.4 \\
\hline
\end{tabular}

Source: EUROSTAT/ROA 


\section{Convergence or divergence}

As Delsen (1991) says, the considerable differences between the EU Member States in labour laws and social security systems regarding both part-time work and temporary contracts partly explain the inter-country differences in the importance of these two forms of atypical employment relations. Divergence on these points may result in an increase in the distortion of competition within the common market of the European Union. Delsen (1991, p. 144) gives an extreme example of such distortions within a common market: 'In this context, transnational operations of temporary employment businesses could recruit a temporary employee on one side of a frontier for the purpose of providing services to a company in a neighbouring country, but not comply with the rules in force in that country'.

The increasing international competition on product markets and the increasing potential labour mobility as a result of the 'harmonisation' of the labour market in the European Union would both be expected to lead to convergence in the prevalence of atypical employment relations in the various Member States. To get an indication of how the proportions of part-time work and temporary contracts in the EU Member States are converging or diverging, we constructed convergence/divergence indicators for both forms of atypical employment for all occupational sectors. This indicator is defined as follows:

$$
C l_{i}=\frac{\sum_{j=1}^{n}\left(X_{i j}-\bar{X}\right)^{2}}{(n-1)}
$$

where:

$\mathrm{Cl}_{i} \quad=$ Convergence (Divergence) Indicator for occupational sector $i$

$\mathrm{X}_{\mathrm{ij}} \quad=$ Percentage of atypical employment in occupational sector $i$ in country $j$

$\bar{X}_{i} \quad=$ Average percentage of atypical employment in occupational sector $i$

$\mathrm{n} \quad=$ number of countries

The value of this indicator in any year is a measure of the degree of harmonisation, whereas the trend over time indicates whether there is a diverging or converging trend. In order to analyze the patterns of divergence or convergence over a somewhat longer period, we extended our analysis to the period 1983-1991. Since the relevant EUROSTAT Labour Force Survey data for this period is only available for 9 Member States, we restricted the analyses to these countries. ${ }^{11}$

11. Italy, Spain and Portugal had to be excluded from these analyses. 


\section{Part-time employment}

Figure 1 shows the time-pattern of the convergence/divergence indicator for the seven occupational sectors distinguished. The figure shows that the degree of divergence differs considerably between the various occupational sectors. The differences in the prevalence of part-time work are highest for the secondary part-time workers in the service and sales occupations, but are also relatively high for the retention part-time workers in the professional occupations. The differences in the prevalences of secondary part-time work among agricultural and production workers are much smaller. ${ }^{12}$

\section{Figure 1}

Divergency/convergency in the proportion of part-time workers by occupational sector (Italy, Spain and Portugal excluded).

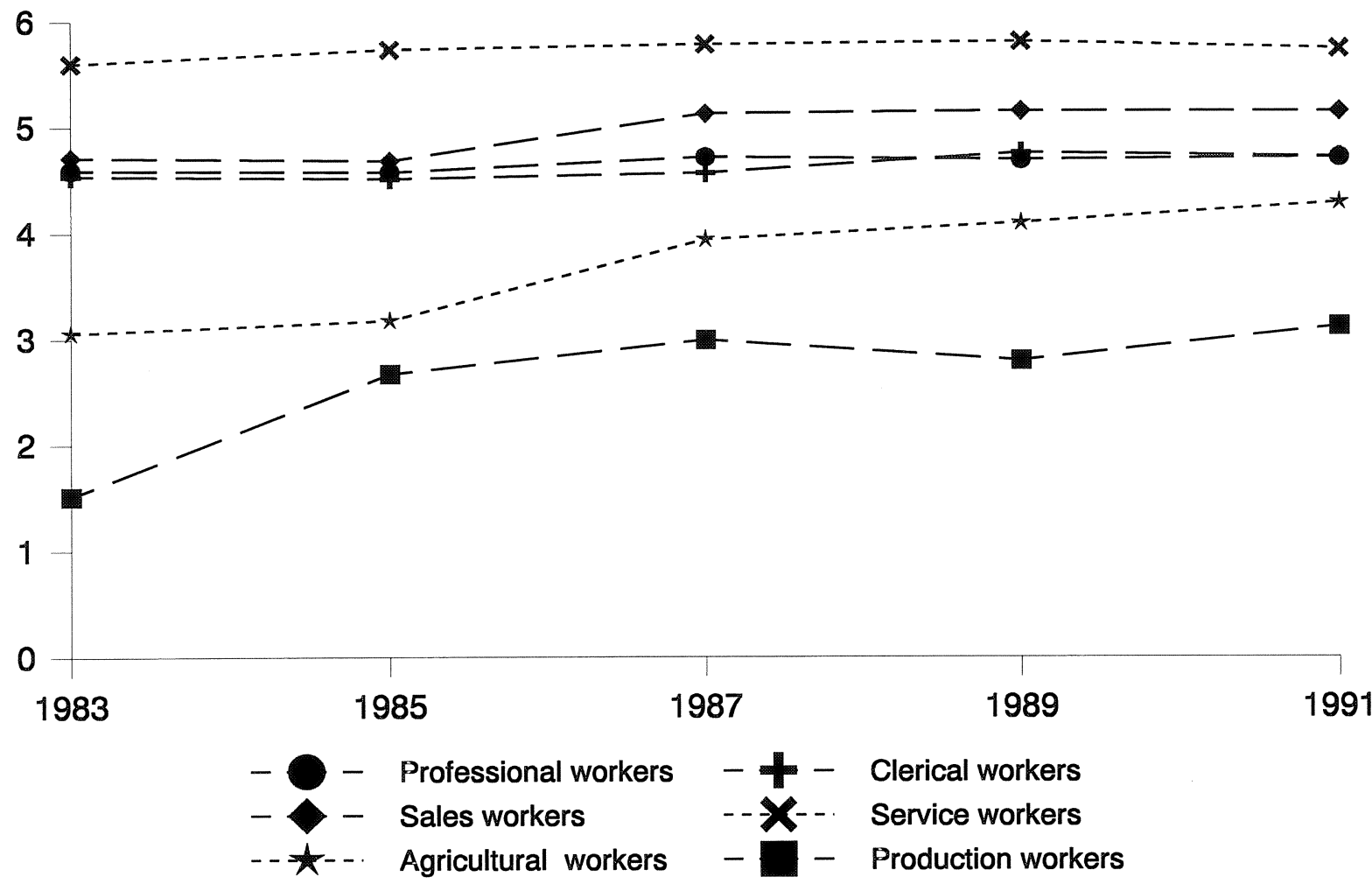

None of the occupational sectors in the figure shows a clear converging trend in the proportions of part-time workers. The occupational sectors with the lowest proportions of part-time workers, the production and agricultural workers, show remarkable divergent tendencies.

12. Due to the relatively low numbers of part-time workers in the managerial occupations, figure 1 does not present the divergency trend for this occupational sector. 


\section{Temporary contracts}

Figure 2 gives an overview of differences in the proportions of temporary work in the various occupational sectors between the EU Member States. If we compare the values of the convergency/divergency indicator in this figure with the indicator values in figure 1 , it can be concluded that the differences in the proportions of temporary work are, in general, much smaller than those for part-time work. The differences for temporary work are highest among production workers, somewhat smaller for service, sales and clerical workers, and lowest of all for professional and agricultural workers.

Several occupational sectors show a slight converging trend in the proportions of temporary jobs in the period 1983-1991. This holds in particular for the professional workers and the agricultural workers. On the other hand the proportions of service workers with temporary work in the Member States are diverging.

\section{Figure 2}

Divergency/convergency of the proportion of temporary work by occupational sector (Italy, Spain and Portugal excluded).

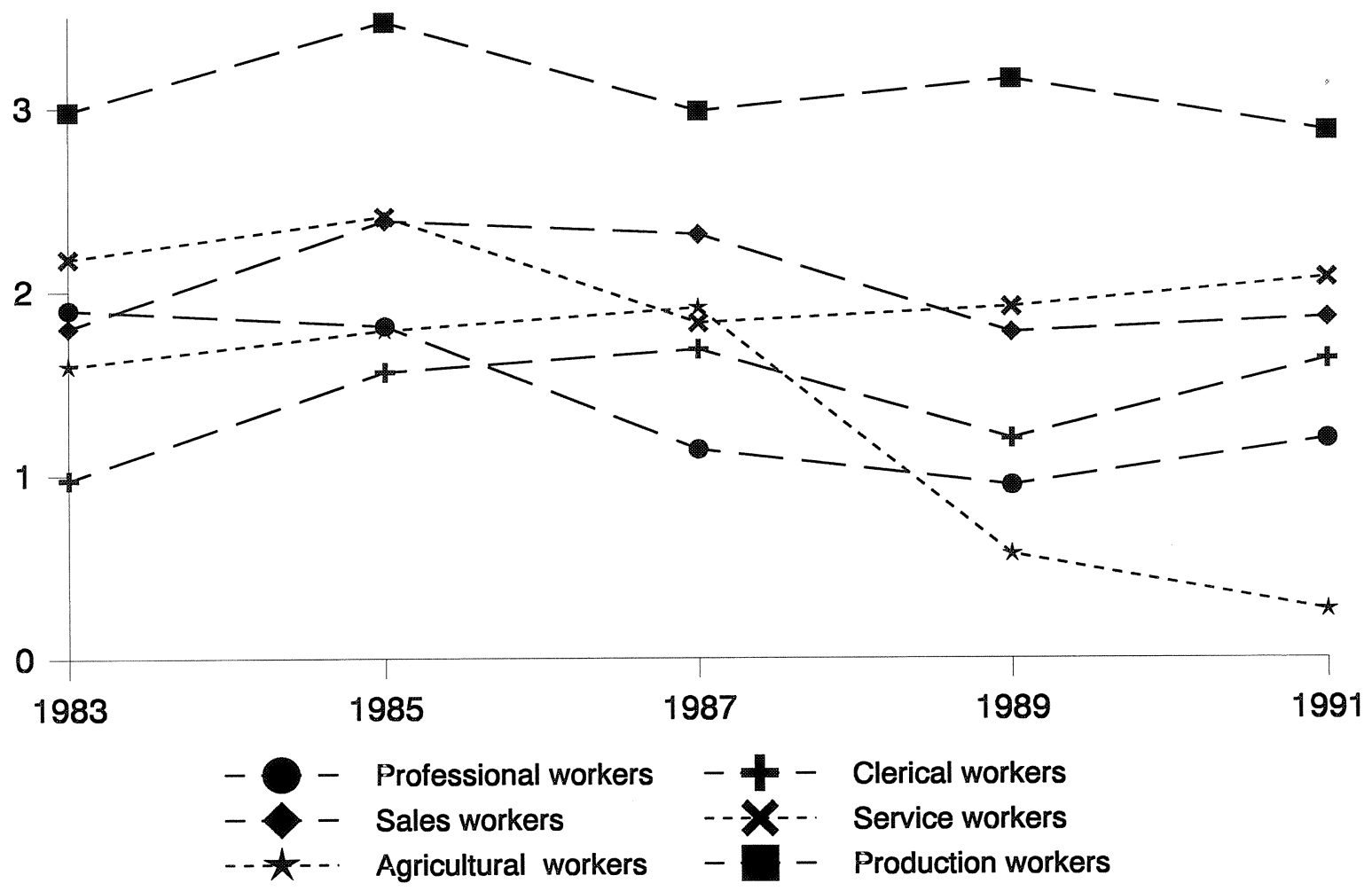




\section{Probabilities of having atypical employment}

To analyze the extent to which supply-side personal and demand-side occupational characteristics determine atypical employment relations, we carried out (modified) binomial logit analyses, both with regard to the probability, or 'risk', of having a part-time job and the risk of having temporary work. ${ }^{13}$ In both cases, the first analysis incorporated the country effect and several supply-side background variables: gender, age category and skill level. We also added a demand-side variable for changes in the level of employment in the occupational field.

Labour market segmentation theory would lead one to expect that, in so far as part-time and temporary work relate to the 'bad' jobs in the secondary labour market segment, female workers, young people, older workers and low-skilled workers would be overrepresented among part-time and temporary workers due to 'statistical discrimination' related to their generally looser links with the labour market (See e.g. Doeringer and Piore, 1971; Reich et al., 1973; Thurow, 1975; Wilkinson, 1981). However, this would not necessarily apply to retention part-time work, although here too, workers with looser links to the labour market are probably over-represented. We would therefore expect positive signs for these personal background variables.

It is not entirely clear what sign we should expect for the employment growth variable. On the one hand, we might expect employers seeking labour in occupational markets which are enjoying high employment growth to prefer to employ as many full-time workers as possible. But in the case of retention part-time work, such firms may in fact be forced to allow more part-time work where workers prefer it. Moreover, if firms are uncertain about the sustainability of the growth pattern, they may prefer to recruit workers with looser links to the labour market. The first argument would lead to a negative sign, whereas the latter arguments would lead one to expect a positive sign for this variable.

Similar arguments apply to the employment growth variable for temporary work. If there is high employment growth, many entrants may be recruited on a temporary basis. But on the other hand, if there is high employment growth, the market situation may force employers to offer their workers permanent contracts. In the first case we might expect a positive sign; in the latter case the variable has a negative sign.

In order to determine to what extent supply-side or demand-side effects determine atypical

13. The model is described in Appendix A. Since EUROSTAT did not give us access to the micro-data of the Labour Force Survey, these multivariate analyses could only be applied to data derived from cross tabulations. 
employment relations we extended the first model with occupational sector domains that indicate whether the probability that particular workers will have atypical labour relations is related to the occupational field in which they are employed.

\section{Part-time work}

Table 7

Estimation results of logit analysis with regard to the probability of working part-time, 1991

\begin{tabular}{|c|c|c|c|c|}
\hline variable & \multicolumn{2}{|c|}{ analysis 1} & \multicolumn{2}{|c|}{ analysis 2} \\
\hline Constant & -3.08 & $(-5.77)$ & -3.43 & $(-5.12)$ \\
\hline Belgium & -0.67 & $(-2.65)$ & -0.51 & $(-1.98)$ \\
\hline \multicolumn{5}{|l|}{ Germany* } \\
\hline Denmark & 0.14 & $(0.55)$ & 0.33 & $(1.60)$ \\
\hline Greece & -1.93 & $(-7.91)$ & -1.75 & $(-6.92)$ \\
\hline Spain & -2.02 & $(-7.28)$ & -1.59 & $(-5.67)$ \\
\hline Ireland & -1.17 & $(-4.90)$ & -0.93 & $(-3.95)$ \\
\hline Netherlands & 0.92 & $(4.07)$ & 1.09 & $(5.09)$ \\
\hline Portugal & -2.53 & $(-7.49)$ & -1.83 & $(-5.43)$ \\
\hline United Kingdom & -0.62 & $(-2.27)$ & -0.03 & $(-0.11)$ \\
\hline Professional workers & & & 0.01 & $(0.01)$ \\
\hline Managerial workers & & & -0.36 & $(-0.80)$ \\
\hline \multicolumn{5}{|l|}{ Clerical workers* } \\
\hline Sales workers & & & 0.60 & (2.91) \\
\hline Service workers & & & 0.92 & $(4.76)$ \\
\hline Agricultural workers & & & 0.53 & (1.16) \\
\hline Production workers & & & 0.19 & $(0.57)$ \\
\hline Annual employment growth (1988-1991) & 0.09 & $(0.20)$ & -0.04 & $(-0.11)$ \\
\hline 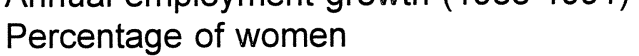 & 4.08 & $(14.25)$ & 3.17 & $(5.36)$ \\
\hline Percentage of young people** & 3.24 & $(2.60)$ & 1.21 & $(0.93)$ \\
\hline Percentage of older workers ${ }^{* * *}$ & 2.36 & (1.85) & 1.43 & $(0.65)$ \\
\hline Percentage of intermediate skilled & -2.28 & $(-4.35)$ & -0.95 & $(-1.45)$ \\
\hline Percentage of highly skilled & -0.18 & $(-0.49)$ & 0.61 & $(0.68)$ \\
\hline \multicolumn{5}{|l|}{ * reference group } \\
\hline \multicolumn{5}{|l|}{ ** $\quad 15-24$ years old } \\
\hline$* * * \quad 55-64$ years old & & & & \\
\hline
\end{tabular}

(t-values between brackets)

Table 7 shows the estimation results with regard to the probability that a worker will have part-time work. From the first analysis we see that several of the supply-side characteristics have the expected sign. High proportions of female workers and young people correlate with significantly higher probabilities of part-time work. The same holds for the employment share of older workers, although the parameter value of this variable is only significant at a $10 \%$ level. As expected, a higher proportion of intermediate skilled 
workers leads to a significantly lower probability of part-time workers. ${ }^{14}$ The variable for the proportion of highly-skilled workers also has the expected negative sign, although the parameter value is not significant. Perhaps because of the opposing effects described above, the parameter of the employment growth variable is not significant. These estimation results confirm the hypotheses above, derived from labour market segmentation theory, and also reflect the 'stylized facts' as shown in, e.g., Rodgers and Rodgers (1989) and Meulders and Plasman (1993).

As might be expected from the figures shown in table 1, the country effects (related to the reference country, Germany) show significant negative effects in Portugal, Spain, Greece, Ireland and Belgium. Surprisingly the same holds for the United Kingdom. In contrast, the Netherlands has a significant positive effect.

The estimation results of the second model, in which the demand-side occupational effects are included, show that the supply-side characteristics produced only one significant result. The proportion of female workers is significantly (positively) related to the probability of having part-time work. Although the explanatory variables for young people, older workers and intermediate skilled workers again have the expected sign, the parameter values for these variables are no longer significant. It appears that the significant effect for these variables in the first model are actually occupational effects.

The country effects in the second model differ little from those measured in the first model, so that it is mainly the significant positive signs for the occupational fields of sales workers and service workers in the second model which replace the age group effects of young people and older workers in the first model. This means that gender is the only personal background characteristic of the workforce which determines the probability of working part-time. Regardless of which occupational sector they work in, women have a higher probability of part-time employment. The apparent higher probabilities that young people and older workers will work part-time, and the lower probability that intermediate skilled workers will do so, are actually related to the characteristics of the occupational sectors in which these workers are employed.

It is also interesting to examine whether the various background characteristics play different roles in explaining supply-side induced retention part-time work and demand-side induced secondary part-time work. We therefore estimated the first model separately for

14. The low-skilled workers are the reference group. 
these two categories of part-time work..$^{15}$ As table 8 shows, however, the only significant effects which apply to both categories of part-time work are country effects and the gender effect. Moreover, the employment share of intermediate skilled workers has a significant negative effect on the prevalence of retention part-time jobs. This could indicate that employers are more inclined to allow highly-skilled workers to work part-time.

Table 8

Estimation results of logit analysis with regard to the probability of working part-time in retention part-time jobs and secondary part-time jobs, 1991

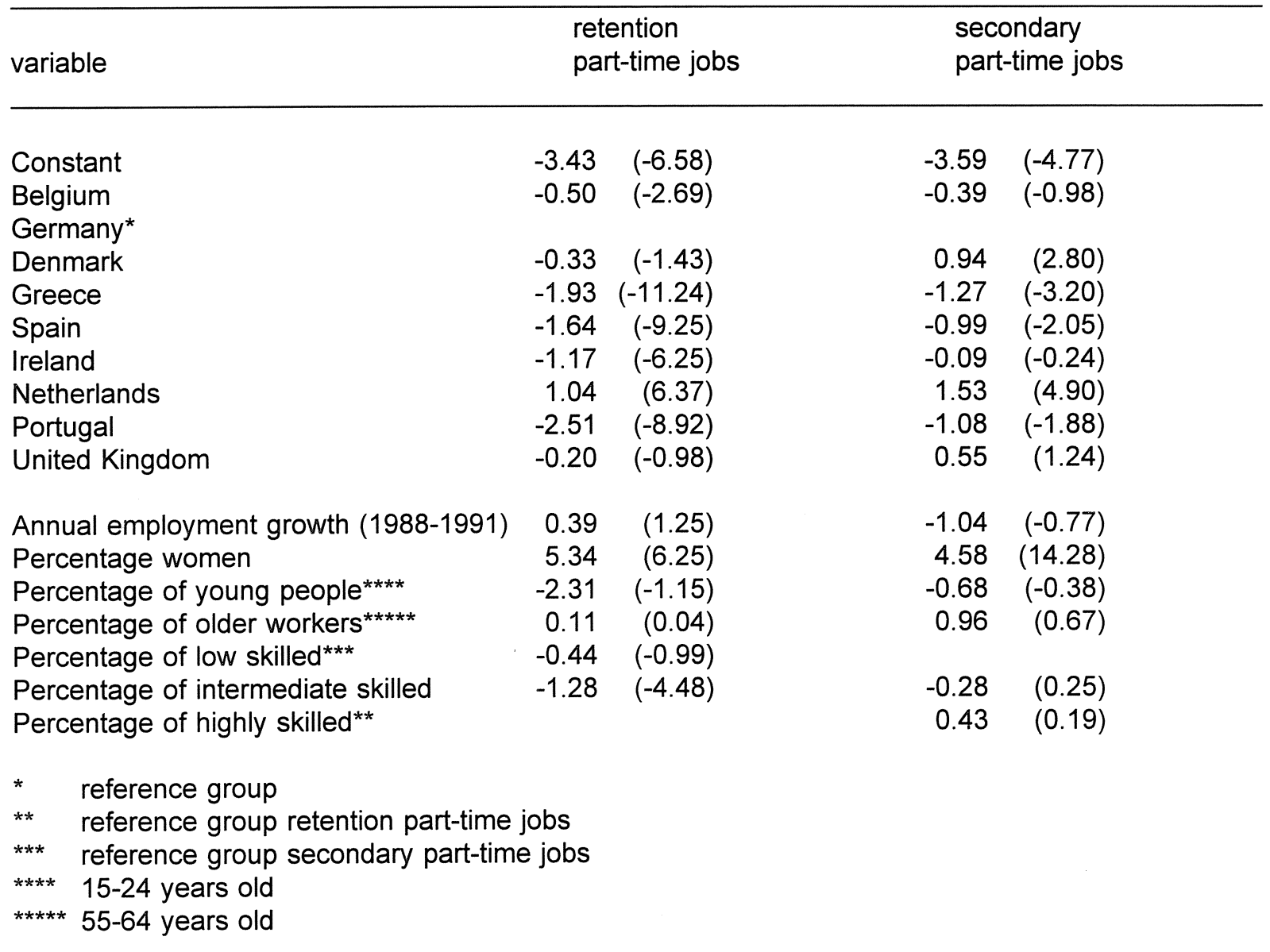

(t-values between brackets)

A comparison of the country effects from the analyses of retention part-time work and secondary part-time work produces some interesting results. The estimation results show significant negative country effects for retention part-time work for the less advanced Southern-European countries (Greece, Portugal and Spain) and for Ireland and Belgium,

15. In this analysis we combined the two categories of retention part-time work which are distinguished in table 2 . In the analysis of retention part-time work, the highly-skilled workers are the reference category, since the low-skilled workers, are hardly employed in these occupational sectors. 
while the Netherlands is the only country with a significantly positive effect for retention part-time work, in comparison with Germany. With regard to secondary part-time work, however, the various country effects are clearly less important. At a $1 \%$ level of significance only Greece has a negative effect, and the Netherlands again has a significant positive effect. The same holds for Denmark, which is quite remarkable since, in the analysis of retention part-time work, Denmark had a negative effect (although not significant) on the probability of part-time employment.

\section{Temporary work}

Table 9 shows the estimation results of the logit analyses with regard to the probability of temporary work. Due to the low numbers of temporary workers in the occupational sectors of managerial and agricultural workers in some countries, we had to exclude these two occupational sectors from the analysis.

The estimation results using the first model show that female workers have a significantly higher probability of having temporary employment, as was expected. As expected, the proportions of workers who are intermediate or highly-skilled have significant negative effects, although the effect for the higher skill category is significant only at a $10 \%$ level. With regard to the older workers, the results for temporary work contrast with those for part-time work. Where there is a high proportion of older workers, this has a significant negative effect on the proportion of temporary contracts. Apparently temporary contracts are not characteristic of the atypical employment relations of older workers. The estimation results also show that the employment share of young people, and the rate of employment growth, do not have a significant effect on the probability of temporary work. The result for young people is rather unexpected, as several authors have pointed to the concentration of temporary jobs among young people (see e.g. Büchtemann and Quach, 1989 and Treu, 1992).

The country effects generally reflect the figures in table 5, with significant negative effects (relative to Germany) for Belgium, the United Kingdom, Ireland and the Netherlands, and a significant positive effect for Spain. If we compare these country effects with the country effects for part-time employment, we see that Belgium, the United Kingdom and Ireland have significant negative effects on both forms of atypical employment. However, Spain and the Netherlands show that the two forms of atypical employment do not necessary run in parallel. Spain has significantly more temporary employment and less part-time work than Germany, whereas the Netherlands has significant less temporary work and more part-time employment.

The estimation results for the second model show that after adding the demand-side 
occupational effects to the model the personal characteristics of the workers no longer have significant effects on the probability of temporary employment. However, due to the correlation between workers' background characteristics and the occupational field in which they are employed, the estimated occupational effects are also insignificant.

Table 9

Estimation results of logit analysis with regard to the probability of having temporary work, 1991

\begin{tabular}{|c|c|c|c|c|}
\hline \multirow{2}{*}{$\begin{array}{l}\text { variable } \\
\text { Constant }\end{array}$} & \multicolumn{2}{|c|}{ analysis 1} & \multicolumn{2}{|c|}{ analysis 2} \\
\hline & -0.92 & $(-1.47)$ & -2.50 & $(-2.51)$ \\
\hline Belgium & -1.35 & $(-4.64)$ & -0.73 & $(-1.96)$ \\
\hline \multicolumn{5}{|l|}{ Germany* } \\
\hline Denmark & 0.30 & $(1.15)$ & 0.26 & $(1.10)$ \\
\hline Greece & -0.30 & $(-1.28)$ & 0.13 & $(0.38)$ \\
\hline Spain & 0.83 & (3.14) & 1.24 & (3.35) \\
\hline Ireland & -0.61 & $(-2.28)$ & -0.37 & $(-1.30)$ \\
\hline Netherlands & -0.57 & $(-2.04)$ & -0.33 & $(-1.19)$ \\
\hline Portugal & -0.25 & $(-0.69)$ & 0.35 & $(0.82)$ \\
\hline United Kingdom & -1.05 & $(-3.62)$ & -0.73 & $(-2.30)$ \\
\hline Professional workers & & & 0.88 & (1.12) \\
\hline \multicolumn{5}{|l|}{ Clerical workers* } \\
\hline Sales workers & & & -0.33 & $(-1.29)$ \\
\hline Service workers & & & 0.19 & $(0.82)$ \\
\hline Production workers & & & 0.08 & $(0.19)$ \\
\hline Annual employment growth (1988-1991) & -0.31 & $(-0.34)$ & -0.52 & $(-0.62)$ \\
\hline Percentage of women & 0.86 & $(2.69)$ & 0.72 & $(0.80)$ \\
\hline Percentage of young people ${ }^{* *}$ & -1.24 & $(-0.90)$ & 1.01 & $(0.63)$ \\
\hline Percentage of older workers ${ }^{* * *}$ & -6.75 & $(-2.09)$ & -1.77 & $(-0.44)$ \\
\hline Percentage of intermediate skilled & -1.56 & $(-2.90)$ & -0.22 & $(-0.29)$ \\
\hline Percentage of highly skilled & -0.73 & $(-1.82)$ & -1.26 & $(-1.12)$ \\
\hline \multicolumn{5}{|l|}{ * reference group } \\
\hline \multicolumn{5}{|l|}{ ** 15-24 year old } \\
\hline$* * * 55-64$ year old & & & & \\
\hline
\end{tabular}

(t-values between brackets)

\section{Conclusion}

This paper has focused on the two major forms of atypical employment relations - parttime work and temporary employment contracts - in the various Member States of the European Union. The analyses were based on EUROSTAT Labour Force Survey data on employment by occupational sector for eleven Member States of the EU (Italy excluded).

On average, $15 \%$ of the total working population in the EU works on a part-time basis. The 
Netherlands has by far the largest proportion in part-time employment, while Greece, Spain and Portugal have relatively small proportions of part-time workers. Moreover, there are very large differences between the various occupational sectors, in all countries. There are many part-time jobs among service workers, in particular. Although the majority of the parttime jobs could be classified as secondary part-time jobs, the percentage of part-time workers in the highly and intermediate skilled occupations is slightly higher than in the lowskilled occupational sectors. The overall rankings of countries with regard to retention and secondary part-time jobs are quite similar.

The percentages of both retention and secondary part-time jobs for female workers are much higher than for male workers. Moreover, women are strongly over-represented in secondary part-time jobs in all countries. The average employment share of part-time workers increased by 1 percentage point in the period 1987-1991. The increase in retention part-time work is much higher than the increase in secondary part-time jobs, probably due to the tightening of the labour market in most EU Member States at the end of the 1980s.

In the European Union, $9.3 \%$ of the total workforce are employed under temporary contracts, which makes temporary employment a substantially less frequent form of atypical employment than part-time employment. The differences between the various Member States are generally not extremely large, with the exception of Spain where almost a quarter of all employment is in the form of temporary jobs. As expected, the larger part of temporary work relates to the 'secondary jobs' in the low-skilled occupational sectors. Remarkably, the average increase in temporary work in the period 1987-1991 was substantially higher than the increase in part-time work. Spain had a particularly strong rising trend in the percentage of temporary contracts. The average growth in temporary work has been highest among service workers and production workers.

We also analyzed to what extent there has been a divergence or convergence between the various EU Member States in the employment shares of part-time workers and temporary employment in the years 1983-1991. This showed that the greatest differences in the prevalence of part-time work are found for secondary part-time jobs among workers in the service and sales occupations and retention part-time jobs among workers in the professional occupations. None of the occupational sectors show a clear convergence in the proportions of part-time work in the various Member States. Remarkably, the occupational sectors with the lowest proportions of part-time employment - production workers and agricultural workers - show a divergence in the prevalancies of part-time work in the Member States.

In general, the inter-country differences in the employment shares of temporary work are 
much smaller than the differences in the proportions of part-time work. The inter-country differences in the proportion of temporary jobs are highest among production workers. In contrast to the patterns with regard to part-time work, several occupational sectors show a slight convergence in the employment shares of temporary jobs in the period 1983-1991.

In addition to these more descriptive analyses, the paper focused on the extent to which supply-side personal background characteristics and the demand-side characteristics of the occupational field determine the probability of atypical employment relations. The analyses of the effects of the supply-side personal background characteristics show that both parttime and temporary work are closely related to female employment. Moreover, high employment shares for low-skilled workers are significantly related to both forms of atypical employment. The proportions of young people and of older workers both have a positive effect on part-time work, whereas the employment share of older workers has a negative effect on temporary employment. However, if the demand-side effects of the occupational field in which workers are employed are included in the analysis, gender is the only background characteristic that increases the probability of part-time work. The higher probabilities of women having temporary contracts and of young people and older workers working part-time, and the lower probability of intermediate skilled workers having part-time employment, are actually related to the occupational sectors in which these workers are employed. In particular, significantly more sales workers and service workers are employed in part-time jobs. Thus if atypical employment relations 'have become the normal mode of entry into the labour market for young workers', as Treu (1992) argues, this could probably be explained by the occupational fields in which young people find their first positions in the labour market.

Estimation results also show that the various background characteristics do not play a different role in high or intermediate skilled retention part-time work and low-skilled secondary part-time jobs. The prevalences of both forms of part-time work are significantly related only to the participation of female workers. Moreover, the estimation results indicate that employers allow highly-skilled workers, in particular, to work part-time. Retention parttime work also appears to be a significantly less important phenomenon in the less advanced Southern-European countries (Greece, Portugal, Spain) and in Ireland and Belgium. The differences between the various Member States are considerably less significant with regards to secondary part-time jobs. Strikingly, Denmark has significantly more secondary part-time work, although it does not have more retention part-time work.

The estimation results also show that the prevalences of the two forms of atypical employment in a particular country do not necessarily coincide. Spain has significantly more temporary employment and less part-time work than in Germany, while the Netherlands has significantly less temporary work and more part-time employment. 


\section{References}

Amemiya, T. and F. Nold (1975), 'A Modified Logit Model', Review of Economics and Statistics, May, 1975, pp. 255-257.

Büchtemann, Chr. F. and S. Quach (1989), "Bridges or traps'? Non-standard employment in the Federal Republic of Germany', in Rodgers, G. and Rodgers, (eds) Precarious jobs in labour market regulation: The growth of atypical employment in Western Europe, Geneva: International Institute for Labour Studies, 109-148.

Burchell, B. (1989), 'The impact on individuals of precariousness in the United Kingdom labour market, in Rodgers, G. and Rodgers, J. (eds), Precarious jobs in labour market regulation: The growth of atypical employment in Western Europe. Geneva: International Institute for Labour Studies, 225-248.

Córdova, E. (1986), 'From full-time employment to atypical employment: A major shift in the evolution of labour relations?', International Labour Review, Vol. 125, 641-657.

Cousins, M. (1992), 'Social security and atypical workers in Ireland', International Labour Review, Vol. 131, No. 6, 647-660.

Delsen, L. (1991), 'Atypical employment relations and government policy in Europe', Labour, Vol. 5, No. 3, 123-149.

Delsen, L. (1993), 'Part-time employment and the utilisation of labour resources', Labour, Vol. 7, No.3, 73-91.

Delsen, L. (1995), Atypical Employment: an International Perspective, Causes, Consequences and Policy, Groningen: Wolters-Noordhoff.

Doeringer, P.B. and Piore, M.J. (1971), Internal labour markets and manpower analysis, Massachussetts: D.C. Heath, Lexington Books.

Hoevenberg, J. and A. de Grip (1994), Indicators of occupational employment in the European Union, ROA-R-1994/3E, Maastricht: Research Centre for Education and the Labour Market.

Judge, G.G., W.E. Griffiths, R. Carter Hill, and T-C. Lee (1980), The Theory and Practice of Econometrics, New York, John Wiley \& Sons.

Kravaritou-Manitakis, Y. (1988), New forms of work: Labour law and social security aspects in the European Community, Dublin: European Foundation for the Improvement of Living and Working Conditions.

Larson, T. and P.M. Ong (1994), 'Imbalance in Part-Time Employment', Journal of Economic Issues, Vol. 28, No. 1, 187-196.

Marshall, A. (1989), 'The sequel of unemployment: The changing role of part-time and temporary work in Western Europe', in Rodgers G. and Rodgers J. (eds.), Precarious jobs in labour market regulation: The growth of atypical employment in Western Europe, Geneva: International Institute for Labour Studies, 17-48.

Meulders, D. and R. Plasman (1993), 'Part-Time Work in EEC Countries: Evaluation during the 1980s', Labour, 7, 49-71.

Meulders, D., O. Plasman and R. Plasman (1995), Atypical Employment in the EC, Aldershot: Dartmonth.

OECD (1993), Employment Outlook, Paris: OECD.

Polivka, A.E. and Th. Nardone (1989), 'On the definition of "contingent work"', Monthly Labour Review, December 1989, 9-16.

Reich, M., D.M. Gordon and R.C. Edwards (1973), 'A theory of labour market segmentation', American Economic Review, Vol. 63, No. 2, 359-365. 
Rodgers, G. (1989), 'Precarious work in Western Europe: The 'state of the debate', in Rodgers, G. and Rodgers, J. (eds), Precarious jobs in labour market regulation: The growth of atypical employment in Western Europe, Geneva: International Institute for Labour Studies, 3-16.

Rodgers, G. and Rodgers J. (eds) (1989), Precarious jobs in labour market regulation: The growth of atypical employment in Western Europe, Geneva: International Institute for Labour Studies.

Thurow, L.C. (1975), Generating Inequality, New York: Macmillan.

Tilly, Chr. (1991), 'Reasons for the continuing growth of part-time employment', Monthly Labor Review, March 1991, 10-18.

Treu, T. (1992), 'Labour flexibility in Europe', International Labour Review, Vol. 131, Nos. 4-5, 497512.

Wilkinson, F. (ed.) (1981), The Dynamics of Labour Market Segmentation, London: Academic Press. 



\section{Appendix A The model}

Let $p_{i j}$ be the probability that workers in country $i(i=1 . . l)$ and occupation $j(j=1 . . \mathrm{J})$ work part-time. ${ }^{16}$ We will try to explain this probability by means of country effects, occupation effects and the educational structure of the labour force by country and occupation.

The model can then be specified in the following logit form (compare Amemiya and Nold, 1975):

$p_{i j}=\frac{\exp \left[\beta_{0}+\beta_{i}+\beta_{j}+\sum_{k} \beta_{k} x_{k i j}+v_{i j}\right]}{1+\exp \left[\beta_{0}+\beta_{i}+\beta_{j}+\sum_{k} \beta_{k} x_{k i j}+v_{i j}\right]}$

in which:

$\begin{array}{lll}\beta_{0}, \beta_{i}, \beta_{j}, \beta_{k} & =\text { parameters; } \\ x_{k i j} & =\mathrm{k} \text { explanatory variables; } \\ v_{i j} & =\text { specification error term. }\end{array}$

Now define (see also Judge et al., 1980, pp. 325-331):

$\beta_{i}^{*}=\beta_{i}-\beta_{l}$
$\beta_{j}^{*}=\beta_{j}-\beta_{J}$

where $I$ is the reference country and $J$ is the reference occupation.

Then equation (A.1) can be rewritten as:

$p_{i j}=\frac{\exp \left[X \beta+v_{i j}\right]}{1+\exp \left[X \beta+v_{i j}\right]}$

where:

$X=\left(j_{I J}\left(\begin{array}{c}I_{l-1} \\ 0^{\prime}\end{array}\right) \otimes j_{J} \quad j_{I} \otimes\left(\begin{array}{c}I_{J-1} \\ 0^{\prime}\end{array}\right) \quad X_{3}\right)$

and:

16. The same kind of model is applied to explain temporary work. 


$$
\begin{aligned}
& \beta=\left(\begin{array}{l}
\beta_{0} \\
\beta_{1}^{*} \\
\beta_{2}^{*} \\
\beta_{3}
\end{array}\right) \\
& \beta_{1}^{*}=\text { vector of parameters } \beta_{i}^{*}(i=1 . . /-1) \text {; } \\
& \beta_{2}^{*} \quad=\quad \text { vector of parameters } \beta_{j}^{*}(j=1 . . \mathrm{J}-1) \text {; } \\
& \beta_{3}=\text { vector of parameters } \beta_{k} \\
& j_{K}=\mathrm{K} \times 1 \text { vector of ones; } \\
& I_{K}=\mathrm{K} \times \mathrm{K} \text { identity matrix; } \\
& X_{3}=\text { matrix of other explanatory variables; } \\
& \otimes \quad=\quad \text { Kronecker's product. }
\end{aligned}
$$

However, the probability $p_{i j}$ cannot be observed. What we do observe is the fraction $f_{i j}$ :

$$
f_{i j}=\frac{\text { observed number of part-time workers } \in \text { country } i \text { occupation } j}{\text { observed total number of workers } \in \text { country } i \text { occupation } j}
$$

This introduces an additional measurement error in the model. According to Amemiya and Nold (1975) this modified logit model can be estimated as follows.

Let:

$$
f_{i j}^{\prime}=X \beta+v_{i j}+u_{i j}
$$

in which:

$$
f_{i j}^{\prime}=\log \left(\frac{f_{i j}}{1-f_{i j}}\right)
$$

The model can be estimated by means of a two stage procedure:

First, the OLS estimator $\hat{\beta}_{1}$ of equation (A.3) is calculated:

$$
\hat{\beta}=\left(X^{\prime} X\right)^{-1} X^{\prime} f^{\prime}
$$


Then define: ${ }^{17}$

$s^{2}=\frac{1}{N-K}\left[\sum_{i j}\left(f_{i j}^{\prime}-x_{i j} \hat{\beta}\right)^{2}-\sum_{i j} \frac{1}{n_{i j} f_{i j}\left(1-f_{i j}\right)}\right]$

in which:

$N=$ number of observations;

$K=$ number of parameters;

$n_{i j} \quad=\quad$ observed number of workers in country $i$ and occupation $j$.

and:

$f_{i j}^{*}=\left[\frac{1}{\sqrt{s^{2}+\frac{1}{n_{i j} p_{i j}\left(1-p_{i j}\right)}}}\right] f_{i j}^{\prime}$

$x_{i j}^{*}=\left[\frac{1}{\sqrt{s^{2}+\frac{1}{n_{i j} p_{i j}\left(1-p_{i j}\right)}}}\right] x_{i j}$

The estimator $\hat{\hat{\beta}}$ for $\beta$ is then:

$\hat{\hat{\beta}}=\left(X^{*^{\prime}} X^{*}\right)^{-1} X^{*^{\prime}} f^{*}$

The variance-covariance matrix of $\hat{\hat{\beta}}$ is:

$\hat{\Sigma_{\beta}}=\left(X^{*^{\prime}} X^{*}\right)^{-1}$

17. Amemiya and Nold use $\mathrm{N}$ instead of $\mathrm{N}-\mathrm{K}$ in this formula. 